\title{
PERSPECTIVES SYSTEM TRANSFORMATION AND DEVELOPMENT ISSUES
}

\section{ПЕРСПЕКТИВИ СИСТЕМНОЇ ТРАНСФОРМАЦІЇ ТА ПРОБЛЕМИ РОЗВИТКУ}

\section{ПЕРСПЕКТИВЫ СИСТЕМНОЙ ТРАНСФОРМАЦИИ И ПРОБЛЕМЫ РАЗВИТИЯ}

\author{
Nosova O. V. \\ Doctor of Economic Sciences, Professor, Department of Marketing, Management and Entrepreneurship. V.N. Karazin \\ Kharkiv National University. E-mail: olgano59@gmail.com
}

Носова О.В.

Доктор економічних наук, професор, професор кафедри маркетингу, менеджменту та підприємництва Харківського національного університету імені В.Н. Каразіна. E-mail: olgano59@gmail.com

\section{Носова О.В.}

Доктор экономических наук, профессор, профессор кафедры маркетинга, менеджмента и предпринимательства Харьковского национального университета имени В.Н. Каразина. E-mail: olgano59@gmail.com

\begin{abstract}
The article aims to study and analyzes the political and social-economic changes in the process of system transformation. The paper represents an attempt to understand the content of system transformation, causes of successful and inefficient practices, and proposes recommendations for its improvement.

The hypothesis of the study is to estimate how the vector development depends on the degree of economic, political, social transformation, as well as the overall indicators (market and democratic) transformation. The study discusses the concepts systemic transformation, describes types of transformation, proposes classification of basic approaches, determines the impact of transformational changes on economic growth in a country, and analyzes the vector development relationship from transformational changes, defines contributing and slowing down factors.
\end{abstract}

Keywords: System transformation, transformational change, economic development, interdisciplinary approach.

Анотація. Стаття спрямована на вивчення та аналіз політичних та сочіальноекономічних змін у процесі системної трансформації. У статті представлена спроба зрозуміти зміст системної трансформації, причини успішних та неефективних практик, запропоновані рекомендащії щзоо ї̈ вдосконалення. Гіпотеза дослідження полягає в оцінці того, як вектор розвитку залежить від ступеня економічної, політичної, соціальної трансформації, а також загальних показників (ринкової та демократичної) трансформації. У дослідженні розглядаються поняття системної трансформації, описуються типи трансформаціï, запропонована класифікація основних підходів, визначається вплив трансформащійних змін на економічне зростання в країні та аналізується взаємозв'язок вектора розвитку від трансформаційних змін, визначаються чинники які сприяють або уповільнюють розвиток.

Ключові слова: трансформація системи, трансформаційні зміни, економічний розвиток, міждисииплінарний підхід. 
Аннотация. Статья направлена на изучение и анализ политических и социальноэкономических изменений в процессе системной трансформации. В статье представлена попытка исследовать содержание системной трансформации, причины успешных $u$ неэффективных практик, предложить рекомендачии для ее совершенствования. Гипотеза исследования заключается в оченке зависимости вектора развития от степени экономической, политической, соџиальной трансформаџии, а также общих показателей (рыночной и демократической) трансформации. В исследовании рассматриваются понятие системной трансформации, описываются типы трансформации, предложена классификация основных подходов, определяется влияние трансформационных изменений на экономический рост в стране и анализируется взаимосвязь вектора развития от трансформационных изменений, определяются факторы способствующие или замедляющие развитие.

Ключевые слова: трансформация системы, трансформационные изменения, экономическое развитие, междисциилинарный подход.

\section{Introduction.}

The paper represents an attempt to understand the content of system transformation, causes of successful and inefficient processes, and proposes recommendations for its improvement with regard to Ukraine.

The study hypothesis is to estimate how the vector of development depends on the degree of economic, political, social transformation, as well as the overall indicators (market and democratic) transformation in Ukraine. The first part of the study discusses the concepts of systemic transformation, describes types of transformation, and determines the impact of transformational changes on economic growth in a country.

At the second part of the paper, we define which types of transformational reforms contribute to GDP growth, and what it slows down it.

The source of information is data of the Bertelsmann Stiftung's Transformation Index (BTI) 20032018, of the Democracy Barometer, World Bank database, Heritage Foundation and national statistics. The methods for research include the interdisciplinary approach - classification of basic system transformation approaches, statistical methods - transformation modelling, and descriptive analysis - economic performance assessment. The used indicators are relevant for analysis, and they are comparable with the theory we applied.

The purpose of research is to analyze the political and social - economic changes in the process of system transformation, and to single out factors that have led to a more sustainable strategy of political and social - economic development.

Recent literature review. A review of the scholarly and refereed literature shows the existence of a wide variety of theories different views, and approaches. The system transformation analyzed in the context of economic, political and social transformation. This process characterizes the democratization of all spheres in the country's life, formation civil society, sequencing reforms, creation new kinds of institutions, and new management mechanisms usage. The application interdisciplinary approach directs to apply the methods used for social problems solution based on systemic comparative analysis of the different disciplines in other areas of knowledge, generating new interdisciplinary principals and instruments. As part of the study, we consider the analysis of the main theoretical approaches of the system transformation without diminishing the role of others.

The system transformation theories reflect complex process combining economic, political, social, and cultural components. The political transformation accompanied by the change from authoritarian to democratic regime. Political transformation includes elimination of the old political system, creation of the new political structures, organization of system functioning based on democratic mechanisms and procedures. Carothers (2002) claims that the transition paradigm rests on the assumption that democratic transitions making up the third wave are being built on coherent, 
functioning states. The process of redesign of state institutions suggests the creation of the new electoral institutions, parliamentary reform, and judicial reform.

According Polanyi (2001) transformation forces various groups to offer their own ways to adapt to the new situation, and the proposed methods reflect both the interests of the group itself and wider public interests. An important role in transformation assigned to governments of states, citizens, and individuals. Hölscher et al (2018) differentiate concepts transition and transformation, referring to change in complex adaptive systems and large- scale societal change processes. Authors draw attention to the implications on study of elements for change. Transition analyses changes in societal subsystems (e.g. energy, mobility, cities), focusing on social, technological and institutional interactions. Transformation refers to large-scale changes in whole societies.

Boettke and Leeson (2015) assert that "political -economic presumptions" reflect different evaluations of the costs and benefits of extending government's reach into the economic domain, which in turn give rise to different "default" positions regarding the appropriate role of government. Beichelt (2012) analyses the levels of democracy new EU members' states, and states that in some dimension which form of the EU's trans and supra-national regulatory system affects the quality of democracy and existing relationship.

Main research results. The classification of basic system transformation approaches presented in table 1. The classification criteria define title, authors, and subject of application, typical attributes and applied methods. We highlighted approaches based on their grouping according to one or more dimensions of transformation. We attempted to unite and analyze the most significant system transformation approaches without decreasing the significance of those not considered in this paper. This approach directed to analyze, and apply the transformation theories for Ukraine. Data use for Ukraine applied for verification and application theories in further sections of article.

Table 1.

Classification of Basic System Transformation Approaches

\begin{tabular}{|c|c|c|c|c|c|}
\hline № & Title & Authors & $\begin{array}{ll}\text { Subject } & \text { of } \\
\text { Application } & \end{array}$ & Typical Attributes & Applied Methods \\
\hline \multicolumn{6}{|c|}{ Approach to one dimension } \\
\hline 1 & $\begin{array}{l}\text { New } \\
\text { transformation } \\
\text { theory. }\end{array}$ & $\begin{array}{l}\text { Pezoldt \& } \\
\text { Koval (2018) }\end{array}$ & $\begin{array}{l}\text { Political } \\
\text { transformation. }\end{array}$ & $\begin{array}{l}\text { The choice of political } \\
\text { regime depends on the } \\
\text { needs of the population. }\end{array}$ & $\begin{array}{l}\text { Institutional } \\
\text { analysis, rational } \\
\text { choice theory. }\end{array}$ \\
\hline 2 & $\begin{array}{l}\text { The microcosmic } \\
\text { evaluations of } \\
\text { modernization. }\end{array}$ & $\begin{array}{l}\text { Goorha } \\
(2017)\end{array}$ & $\begin{array}{l}\text { Political } \\
\text { transformation. }\end{array}$ & $\begin{array}{l}\text { The role of political } \\
\text { communication and the } \\
\text { media, bureaucratic } \\
\text { corruption. }\end{array}$ & $\begin{array}{l}\text { Macrocosmic } \\
\text { studies of } \\
\text { modernization. }\end{array}$ \\
\hline 3 & $\begin{array}{l}\text { Organization } \\
\text { theory of law. }\end{array}$ & $\begin{array}{l}\text { Baron } \\
\text { \&Wilkinson- } \\
\text { Ryan (2018) }\end{array}$ & $\begin{array}{l}\text { Political } \\
\text { transformation. }\end{array}$ & $\begin{array}{l}\text { The legal and political } \\
\text { institutions play the central } \\
\text { role in allocation power } \\
\text { within a society. The law's } \\
\text { application needs reducing } \\
\text { the probability or harm of } \\
\text { impulsive choices. }\end{array}$ & $\begin{array}{l}\text { Behavioral theory. } \\
\text { Behavior rules for } \\
\text { asymmetric } \\
\text { distribution } \\
\text { properties approach. }\end{array}$ \\
\hline 4 & $\begin{array}{l}\text { Structural } \\
\text { transformation. }\end{array}$ & $\begin{array}{l}\text { Herrendorf, } \\
\text { Rogerson, } \\
\text { Valentinyi } \\
(2013) \text {. }\end{array}$ & $\begin{array}{l}\text { Economic } \\
\text { transformation. }\end{array}$ & $\begin{array}{l}\text { The reallocation of } \\
\text { economic activity across the } \\
\text { broad sectors agriculture, } \\
\text { manufacturing and services. }\end{array}$ & $\begin{array}{l}\text { Theory of social } \\
\text { capital. Qualitative } \\
\text { approach. }\end{array}$ \\
\hline
\end{tabular}




\begin{tabular}{|c|c|c|c|c|c|}
\hline 5 & $\begin{array}{l}\text { Social capital as a } \\
\text { "product of } \\
\text { government } \\
\text { institutions }\end{array}$ & $\begin{array}{l}\text { Thomas \& } \\
\text { Hendrick- } \\
\text { Wong, (2019) }\end{array}$ & $\begin{array}{l}\text { Social } \\
\text { Transformation. }\end{array}$ & $\begin{array}{l}\text { The more productivity } \\
\text { segments of the society } \\
\text { would generate new } \\
\text { opportunities for more } \\
\text { productive activities that } \\
\text { would benefit. }\end{array}$ & $\begin{array}{l}\text { Qualitative } \\
\text { approach. } \\
\text { Interdisciplinary } \\
\text { methods for } \\
\text { political, economic } \\
\text { and sociology } \\
\text { research. }\end{array}$ \\
\hline \multicolumn{6}{|c|}{ Approach to two dimensions } \\
\hline 6 & $\begin{array}{l}\text { The stabilization } \\
\text { of the post } \\
\text { socialist state in } \\
\text { orbit of the } \\
\text { planetary system. }\end{array}$ & $\begin{array}{l}\text { Glinkina \& } \\
\text { Koval (2015) }\end{array}$ & $\begin{array}{l}\text { Political } \\
\text { transformation. } \\
\text { Economic } \\
\text { transformation. }\end{array}$ & $\begin{array}{l}\text { The criteria for completing } \\
\text { the post-socialist transition } \\
\text { is stabilization of post } \\
\text { socialist state being geo- } \\
\text { economic center of } \\
\text { attraction or formation such } \\
\text { center by the country } \\
\text { independently. }\end{array}$ & $\begin{array}{l}\text { Multilevel analysis } \\
\text { of post-communist } \\
\text { transformations for } \\
\text { social-economic } \\
\text { effects. }\end{array}$ \\
\hline 7 & $\begin{array}{l}\text { Path dependency } \\
\text { approach in } \\
\text { cognitive and } \\
\text { institutional } \\
\text { economics }\end{array}$ & $\begin{array}{l}\text { Gigante } \\
(2016)\end{array}$ & $\begin{array}{l}\text { Economic } \\
\text { transformation. } \\
\text { Social } \\
\text { transformation. }\end{array}$ & $\begin{array}{l}\text { The interpretations of } \\
\text { economic behavior, through } \\
\text { the explanation of } \\
\text { individual and social } \\
\text { mechanisms. }\end{array}$ & $\begin{array}{l}\text { Mechanisms of } \\
\text { standardization and } \\
\text { change of } \\
\text { institutional norms. }\end{array}$ \\
\hline 8 & $\begin{array}{l}\text { New Institutional } \\
\text { Economics. } \\
\text { (Institutional } \\
\text { Transplantation). }\end{array}$ & $\begin{array}{l}\text { Zweynert \& } \\
\text { Goldschmidt } \\
(2006)\end{array}$ & $\begin{array}{l}\text { Political } \\
\text { transformation. } \\
\text { Social } \\
\text { transformation. }\end{array}$ & $\begin{array}{l}\text { The allocation of formal } \\
\text { and informal rules. } \\
\text { Institutional structure of the } \\
\text { state, real institutes } \\
\text { (organizations), household } \\
\text { systems. }\end{array}$ & $\begin{array}{l}\text { Sociological } \\
\text { evolutionary theory, } \\
\text { an integrated } \\
\text { approach to } \\
\text { household systems' } \\
\text { analysis. }\end{array}$ \\
\hline 9 & $\begin{array}{l}\text { Neo Institutional } \\
\text { Economics. } \\
\text { (Varieties of } \\
\text { Capitalism). }\end{array}$ & $\begin{array}{l}\text { Drahokoup } \\
(2009) .\end{array}$ & $\begin{array}{l}\text { Political } \\
\text { transformation. } \\
\text { Economic } \\
\text { transformation. }\end{array}$ & $\begin{array}{l}\text { Analysis of property rights. } \\
\text { Transaction costs. } \\
\text { Organizational forms of } \\
\text { behavior in contract's } \\
\text { relations. }\end{array}$ & $\begin{array}{l}\text { Principle of } \\
\text { methodological } \\
\text { individualism. } \\
\text { Rational behavior of } \\
\text { economically } \\
\text { isolated agents. } \\
\end{array}$ \\
\hline \multicolumn{6}{|c|}{ Approach to three dimensions } \\
\hline 10 & $\begin{array}{l}\text { The model of } \\
\text { sociopolitical and } \\
\text { economic } \\
\text { transition. }\end{array}$ & $\begin{array}{l}\text { Boaky } \\
(2007)\end{array}$ & $\begin{array}{l}\text { Transformation of } \\
\text { various levels. }\end{array}$ & $\begin{array}{l}\text { The social integrative } \\
\text { process reallocates } \\
\text { resources from inefficient } \\
\text { use (political power } \\
\text { struggle or even political } \\
\text { conflicts) to efficient use } \\
\text { (production). }\end{array}$ & $\begin{array}{l}\text { Models of social } \\
\text { fragmentation, } \\
\text { dynamics of output } \\
\text { per-capital, } \\
\text { economic growth. }\end{array}$ \\
\hline 11 & $\begin{array}{l}\text { Substantial change } \\
\text { of political and } \\
\text { social systems. }\end{array}$ & $\begin{array}{l}\text { Merkel et al. } \\
(2019)\end{array}$ & $\begin{array}{l}\text { Transformation of } \\
\text { various } \\
\text { institutions' levels. }\end{array}$ & $\begin{array}{l}\text { The change of the } \\
\text { institutional environment, } \\
\text { and patterns of behavior, of } \\
\text { economic agents. The } \\
\text { alteration of the entire } \\
\text { social structure of } \\
\text { institutions. }\end{array}$ & $\begin{array}{l}\text { Multidisciplinary } \\
\text { approaches and } \\
\text { methods. The } \\
\text { decisions of } \\
\text { intentionally acting } \\
\text { subjects. Macro- } \\
\text { qualitative, } \\
\text { comparative } \\
\text { methods. }\end{array}$ \\
\hline
\end{tabular}

Source: Author's approach for classification.

\section{Approach to one dimension}

We will continue our study with analysis of approaches based on one dimension of transformation. Pezoldt \& Koval (2018) proposes new transformation theory that explains changes in economic systems are dependent on the needs of citizens. Thus, the choice of political regime depends on the needs of the population, and there is no predetermined direction of transformation. Authors apply institutional analysis and rational choice theory to justify the necessity of political transformation. They emphasize political transformation, and consider that this theory defines the 
form of the relation, which depends on those mechanisms that set in emotion the transformation processes within the subsystems (Pezoldt, Koval, 2018).

Further political transformation research turns our attention to the modernization theory that deals with the process of adapting something to modern needs or habits. The concept of political modernization applies to countries transitioning from traditional to modern industrial society. With regard to the microcosmic evaluations of modernization Goorha (2017) notes that it emphases on the componential elements of social modernization such as urbanization, gender and income inequality, skills acquisition and education, the role of political communication and the media, bureaucratic corruption, and so on. At a broader level are the macrocosmic studies of modernization focused on the empirical trajectories and manifest processes of the modernization of nations and their societies, economies, and polities. Wallace \& Haerpfer (1998) assert that a particular model of political, economic and societal modernization dominated in East European countries based up a version of Marxist theory.

Further research led to the study the behavioral theory, describing the political transformation as some changes in human behavior. Behavioral approach studies the influence of social, cognitive and emotional factors on economic behavior, economic decision-making by individuals and institutions, and the consequences of this effect on market variables. Behaviors' based theory of motivation indicates that by manipulating certain behaviors in employees, they are more or less likely to perform. Teitelbaum \& Zeiler (2018) emphasize behavior economic theories, and draw attention on motivation theory. Firms exploit technological complementarities along the supply chain. This reduces transaction costs, and increases consumer surplus. The firm's opportunistic behavior is directed to gain control over production processes. The application behavior theory for company's activity provides basis for overcoming informational imperfections, and externalities' internalization. Authors emphasize that these theories are the key to understanding potential motivations behind exclusionary arrangements. Motivations drive our regulatory intuitions increase their market power in other markets or give advantage of their monopoly positions.

The legal forms of behavior are the subject of works discussing organization theory of law. The legal and political institutions play the central role in allocation power within a society. They constrain political decisions via the application of law enforcement mechanism. Baron \&WilkinsonRyan (2018) argue that the forces that produce irrational biases are not fully understood, and are likely to remain. Nevertheless, civilization and its army of educators will be waging a constant battle against these forces, but they will probably continue to exist. Thus, the design of the law and its application may need to consider how it can deal with irrationality for the foreseeable future. Scientists draw attention to on legal approaches to reducing the probability or harm of impulsive choices.

The behavior theory use is directed to the consolidation of the new set of behavior rules with asymmetric distribution properties. It causes the improvement of the negotiation process of all participants in the contract process. The evolution of power relation of economic agents affects the people's behavior. The process of learning influences the change of informal patterns of behavior. They include the problem of credit, labor relations, asymmetric information, and opportunistic behavior. The regulation of economic activity of social agencies provided via the negotiation process. The coordination problem connected with the behavior of economic agents. The absence of getting of any advantages of different people's groups destroys the basis of the domination of the representatives of oligarchy, and corrupted groups in the institutional structure.

Economic transformation involves a series of reforms, the substitution of one system of resource allocation for another. Reform approaches undertaken after 1990 in Central and Eastern European countries considered pragmatic and lacked a theoretical fundament. Gomulka (1994) derives four phases for a typical transition. Phase one focuses on macro stabilization, phase two - on structural adjustment, phase three - on the recovery of growth, and phase four - on sustaining growth and macroeconomic balance. The theory of the structural transformation of social 
production formed as a comprehensive analysis result of a qualitatively new economic situation. It directed to discover the characteristic features of the emerging post-industrial economic system. Scientists argue that structuration processes embedded in and were dependent on changing international and transnational context conditions offering opportunities for developing in new directions (Merkel et al, 2019, 361). Considering the structural transformation of social production, the vast majority of researchers mention the radical acceleration of technological progress. This process accompanied with a decrease in the share of material production in the total social product, the development of the services and information sector, a change in the motives and nature of human activity, as well as the emergence of a new type of resource. Structural transformation refers to the reallocation of economic activity across the broad sectors agriculture, manufacturing and services (Herrendorf et al., 2013).

The social transformation reflected in the theory of social capital, designating the social forms of communications, leading to the development and accumulation of new skills and knowledge. Social capital defines as a "product of government institutions", as dependent on how groups make their own choices or decisions, and it produced through "purposive external interventions" (Thomas \& Hendrick-Wong, 2019, 64). The authors argue that under conditions of inclusive growth (absence of barriers of exclusion,), when some parts of the society are enjoying faster growth in productivity than others, it results in a "win-win" - situation. The more productivity segments of the society would generate new opportunities for more productive activities that would benefit even those who are slower moving or less successful, pulling the entire society along. In this regard, democratizing productivity is also the most productive way of improving income equality (Ibid, 2019, 10).

Theory of social transformation describes transformation process via defining forms of social relations, institutional and system change. Sociology approach deals with the concepts of social structure, social capital, and system of social relations. The social transformation questions are deeply discussed in the in works by Simmel, Parsons, and lately by Luhmann, Beck, Giddens, Habermass and others. Social transformation defines through social changes in institutions, norms, values, and hierarchies, and results in the formation of civil society. Thus, managing economic units as well as global business requires balancing forces between homogenization and differentiation. In order to rephrase the issue: the management of the trade -off between integration and variety (for example cultural responsiveness) can be informed by an evolutionary account of how social systems unfold (Ioannides, 2008, p. 200).

Zaslavskay (2010) characterizes the transformational society structure as the system of social subjects at macro, meso and micro levels, interaction which defines the driving force behind the transformation process._Gurenkova (2016) holds the views that social disintegration provides the separation of elements that united. The most common forms of disintegration are the collapse or disappearance of shared social value, shared social organization, institutions, norms and common interests.

Cultural Economics approach Guiso, Sapienza and Zingales (2006) consider the dependence of impatience and our respect for laws degree as cultural phenomenon. All economic decisions have cultural components. They compound personal preferences, expectation formations, and perception of risk. Such approach influences the essence of majority economic concepts. The economy and culture are inseparable.

Culture can also affect behavior and outcomes through its effect on political preferences of individuals about what governments should do: for example, how much government should interfere in economic life. Competition, market regulation, income redistribute, social security program, nationalization of certain industries and businesses relate to the government's regulation functions of economy (Guiso et al., 2006, 40).

\section{Approach to two dimensions}

The two dimensions of political and economic transformation investigated in a number of works of Western and East European scientists. Glinkina and Kulikova (2010) apply the methodology of the multilevel analysis of post-communist transformations for social-economic 
effects assessment of system transformation in Central East European countries. The "socialist development period" perceived as a "lapse" from historical development process for humanity (an experiment, crime, etc.) and, accordingly, transformation transition as a return to the bosom of civilization. Transition analyses through borrowing existing West type institutions in the developed countries in the hope of catching up with modernization. Scientists propose the hypothesis that the stabilization of the post socialist state in orbit of the planetary system built by geo-economic centers of attraction. This practice leads to the result that in form the same economic processes taking place in different groups of post-socialist countries filled with significantly different contents.

Many researchers apply path dependency theory to explain the sequencing institutional reforms and practices. Path dependency theory explains how the set of decisions one faces for any given circumstance. It is limited by the decisions one has made in the past or by the events that one has experienced. This theory refers to a dynamic property of allocative processes. It may be defined either with regard to the relationship between the process dynamics and the outcome(s) to which it converges, or the limiting probability distribution of the stochastic process under consideration (David, 2010).

Gigante (2016) proposes path dependency theory in cognitive and institutional economics. It is non-linear processes, which can be split in multiple steps: each of them follows a specific direction, according to non-ergodic and upsetting pressures. The author investigates the dependent character of learning processes, shown by cognitive and neurobiological studies, and suggests interpretations of economic behavior, through the explanation of individual and social mechanisms intervening in learning processes, but it has also clarified some mechanisms of standardization and change of institutional norms.

The use of path dependency theory for economic and social transformation study illustrates incomplete transition in Ukraine. Discrete system transformations are historical exceptions quite often triggered by crises. In the end, they generally level off into evolutionary development. Merkel et al. (2019, 2 - 5) affirm that three elements introduced into what has now become political transformation theory: actors, decision, and contingency. A short interval between political regime change and onset of economic transformation, and a fast pace of reform will increase transformation package, and will reduce political bargaining costs (Ibid, 359). The great socioeconomic changes thus give up the way to the problematic of the short-term behavior of concrete actors that may lead to genuine transformation.

The disappointing results of the economic reforms and incomplete transition in the majority of East European countries raise questions to single out and apply such theory that could be a methodological and theoretical basis for the justification and practical implementation of the program for transforming countries. Scientists are looking at the institutional theories, which, in their arsenal, along with economical methods, use sociological, legal, and political science research tools. The expansion of the object of institutional analysis and the inclusion in it norms, rules, forms of organizational behavior allow us theoretically and methodologically to explain the current changes and suggest measures at accelerating the transformation process. "Under institutes, - points out Knight (1992), - we will consider a set of the rules, with the help of which confirms definitely established relationships in the company. The knowledge of these rules and their fulfillment are necessary and should be executed by all members of company." The market acts by the economic regulator ensuring effective operation of a market system. It provides selection institutions. The priority relates to those institutions, which everyone provides the rational behavior of the economic agents, and result in minimization of transaction costs.

The institutional approach explains the emergence of institutions, elucidates the institutional order, and assesses the institutional change. Scientists distinguish the transformation from any kinds of reforms in the society through the results of system changes in the completely political and economic structure of the state. North (1990) believes that institutional change shapes the way societies evolve through time and hence is the key to understanding historical change. 
The institutional methodology provides the mechanism for individual choice of economic agents, and use of constraints methods. They determine the mode of the interrelation between organizations and economic agents. The institutions consider as the internal constraints for economic behavior of agents, functioning in the economic system. The aggregate formal and informal behavior rules explain via the institutions. Tridico (2014) affirms that the behavior of economic agents affected not only by formal institutions such as law, new constitutions and organizations, but also by social norms, old values and habits (informal institutions).

The new institutional economy is studying various government structures, the elements of which are the contract system, organizations (institutions), and the institutional structure of society. Clague (1997) addresses the institutions free standard economics, and it offers ideas for the reform of institutions that are quite different from the moral exhortations of incentive -free engineering. The author points out an important role in how people change their mental models of work behavior.

Zweynert \& Goldschmidt (2006) suggest the two dimensions of political and economic transformation approach as institutional transplantation. They consider the borrowing process of political institutions, business fashions, management practices and policies from one country to another. The informal settings are interpreted in the different countries interacted with the imported formal institutions. Sociological evolutionary theory and an integrated approach to household systems' analysis apply for explanation institutions transfer from one subsystem to another.

The neo-institutional economy investigates property rights, organizations, and political regimes. The main areas of this approach are the theory of property rights, agents and transaction costs, and the theory of public choice. The subject of the neo-institutional economy considers transformation and institutional change from broader overview of legal and economic factors. This approach defines the foundations of the rational behavior of economically isolated agents, the decision - making process, and the forms for property rights protection. The system of property rights determines the use of scarce resources, methods of profit maximization in different socialeconomic systems. The concept of property rights uses for system transformation research. Drahokoup (2009) analyses the regulation theory in the context of institutional concepts and states the predominance of the application the varieties of capitalism's concept in Eastern Europe and the former Soviet Union. He notes that the core ideas of this approach are not only offered analytical tools that have become a leading paradigm in the comparative political economy of Western societies, but also provided rationale for saving European capitalisms from the ideological attack.

Institutions vary in accordance with the notion of the rules of corporate governance and their use. Property rights determination stimulates the rational behavior of economic agent with minimized transaction costs. The institutional transformation efficiency depends on the change of the old institutional order and the establishment of the new order in East European countries.

The institutional order characterizes with the pattern of the standard behavior of economic agents, and methods of coordination, collaboration and strengthening local public policies. A discretionary bargaining model of coordination is more likely to be successful when national leaders share a policy diagnosis that both cuts across economic issue areas and divides their own domestic political coalitions and governments. International organizations may facilitate policy coordination under a rule-based system through provision of resources to ease adjustment costs and rule clarification, and in a discretionary bargaining system by brokering, providing information and model building (Kahler, 1988). Technological progress stimulates the creation of new institutions, and provides the redefinition of the commitments in the society. Entrepreneur's activity stimulation affects the saturation of internal needs of market, and causes the development of the national production. An economic agents' behavior, organizations on a standard sample and ways of their economic coordination perceive under the institutional order. 
Taking into account the institutional order, we should consider the role of institutional change by setting rules and expectations for human interactions. An institutional change actuates the replacement of the old institutional order on the new order. The economic behavior coordination systems of economic subjects subdivided depending on forms of organization on hierarchical and non-hierarchical principals. The economic development accompanied by the institutional change of the forms of the behavior of economic agents.

The scientific works' analysis considering an interaction between political and economic transformation shows their dualistic character. This manifests in the fact that changes in the political system considered in collaboration with relevant reforms in economic system, which affects the direction of its transformation. The applied method does not take into account the impact of other subsystems and analyses external factors. The following approach limits the research subject, excluding legal, social, cultural spheres and others.

\section{Approach to three dimensions}

The limitation of one and two dimensions' approaches study to system transformation brings us to the conclusion to broad the investigation and include in it political, economic and social transformation. The presentation three dimensions' approach contents political, economic and social transformation. Boaky (2007) suggests the model of sociopolitical transition that links sociopolitical transformational process of countries to dynamic process of output per capita and economic growth. The model demonstrates that correction of social integrative processes depends on the degree of social fractionalization, on the level of social distance between the groups, on the level of production technology, and others.

The inclusion into the analysis various institutional levels provides the multidisciplinary approach use. The accumulation of knowledge and changes in values explained by evolutionary way. Institutions may likewise have originated in an evolutionary form. Concerning formal institutions, their modification, as a rule, takes place consciously. Institutional transformation is a set of transformations aimed at creating an effective institutional-market system of society, ensuring the best of the existing alternative options for the allocation of limited institutional resources (Nosova, 2017).

In this context, Merkel et al. (2019, p.4) use the multidisciplinary approach, and consider transformation as substantial change of social systems, which may involve spontaneously, but is mostly caused by the decisions of intentionally acting subjects. Scientists affirm that political, social, cultural, and economic research approaches complement each other. The multidisciplinary approach application permits to overcome the limitations of narrow individual concepts. The institutional system transformation accompanied by institutional environment, patterns of behavior of economic agents' changes.

An overview of research approaches from the political, social, cultural, and economic sciences prove the complementary character for theoretical basis and applied methods. Applications of a number of concepts to system transformation exhibit the common features, and some peculiarities for methodology and analysis. The common feature of all under consideration approaches is a study of some separate direction of system transformation, and its relationship with political, economic and social subsystems. An application of analyzed concepts demonstrates impossibility of explanation transformation within a coherent theory or by applying universal research method. The theoretical analysis illustrates the limitation of empirical research in any specified transformation trend, and causalities within the analyze system. Some scientists apply approaches, combining several areas of transformation research or suggest limited research of certain narrow question. The typical attributes of system transformation theories include defining the basic individual historical, political, economic, social characteristics applying for understanding transformation changes in East Europe. The applied methodology emphasizes the broad variety of 
methods using in social research including behaviorism, structuralism, post-structuralism, realism, modernism, institutionalism, pluralism, rational choice theory and etc. Further research of system transformation needs for future reevaluation processes in East European countries. An application of interdisciplinary approach will contribute to positive shift of research paradigm in the direction of deep understanding the system transformation as a process, and its mechanisms.

\section{Successes and Failures of System Transformation}

Theoretical analysis of numerous studies to system transformation in East European countries tackles some fundamental questions the prerequisites and factors for its successful implementation. The widespread econometric methods and techniques applied for modelling transformation in the works defining phases and stages transformation modelling, human, political and economic development empirical works etc. Henderson (2019) proposes appropriate models related to system transformation approach to one dimension. Author assess economic transformation, and points out that transition path was assumed free market capitalism and democratic state forms. Herrendorf et al (2013) argue that this multi-sector model serves as a natural benchmark to study structural transformation and that it is able to account for many salient features of structural transformation. The multi-sector model delivers new and sharper insights for understanding economic development, regional income convergence, aggregate productivity trends, hours worked, business cycles, and wage inequality. Aisen \& Veiga (2011) apply system transformation approach to one dimension, and use the system-GMM estimator for linear dynamic panel data models and find that higher degrees of political instability are associated with lower growth rates of GDP. Kaldaru \& Parts (2008) follow approach to two dimensions, and study social and economic transformation. Social capital determines with resources and social relations. Scientists estimate the impact of macro-level social capital and related social factors on economic development in 34 European countries. The results of the regression analysis proved that all components have a positive effect on economic development, measured by the human development index.

Hodgson (2006) utilizes approach to three dimensions, including political, economic and social transformation. He applies regression analysis for GDP per capita for 24 countries correlation estimation from various variables. The author identifies the statistically significant variables the degree of ethnic fractionalization and an index of democracy, both of which negatively correlated with GDP and GDP growth. Less scientific work has been done on the impact of system transformation on societies or national economies and one can mention of the lack such estimations have been applied effectively for Ukraine.

The analysis of Bertelsmann Transformation Index for Ukraine from 2003 to 2018 comprises the political transformation index, economic transformation index, transformation management index, and status index. Each of the indices based on the estimation of sub-indices, which reflect the quality of reforms, sequencing, and transparency. Status index evaluates the quality of democracy, a market economy and political management. Bertelsmann Transformation Index aggregates the results into two indices: the status index evaluates the state of political and economic transformation; the management index assesses the quality of governance. Political transformation evaluates the quality of democracy. Political instability is increasing, while trust in democratic institutions is falling. Economic transformation index estimates market economy.

The management index assesses the quality performance over estimated period.

The figure 1 the development of political transformation index, economic transformation index, transformation management index, and status index demonstrates linear relationship between variables in the index form. It should be noted that these data do not provide comprehensive information on the successes or failures of political and economic transformation. 


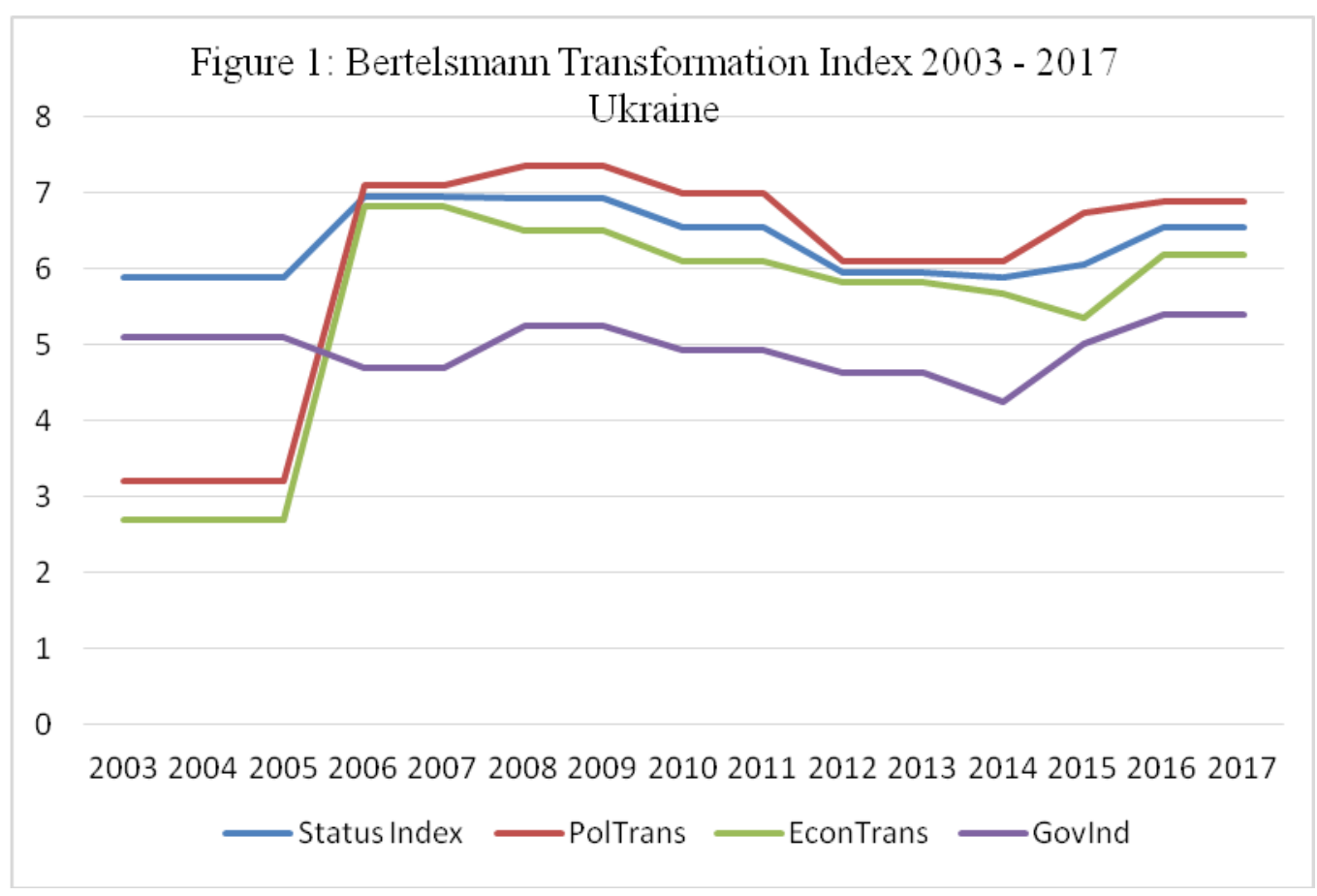

Source: authors' calculations based on Bertelsmann Stiftung data.

The figure 1 shows upward movement curves of all indices in 2006-2007. Afterwards we can see moderate decrease in all curves in 2013-2017, and slight upward increase. In general, the development of all transformation indices has limited power to explain the multidimensional transformation process. The period of 2003-2017 characterized by various political, economic and social changes for the time of being in power the president L. Kuchma (1996 - 2004). The Orange Revolution (late November 2004 - January 2005) was the first active protests against unfair elections. V. Yushenko (2005-2010) and V. Yanukovych (2010-2014) were the next elected presidents. After "Maidan" uprising acting president O. Turchiniv (23 February - 7 June 2014)) has been appointed. P. Poroshenko (2014 - 2019) was the next president in Ukraine. Ukraine has made some progress in improving its economic institutions and implementing structural reforms after election new President V. Zelensky (2019).

In order to check the theory of substantial change of political and social systems (Merkel et al., 2019) and the model of substantial change of political and social systems Boaky (2007), and we provide analysis of the interdependence system transformation from political, economic and social changes. The system transformation considers as a complex process, including various forms of institutional, behavior and structural changes.

First, we focus on the relation between GDP and government stability. A causal hypothesis could be that the government stability has a positive effect on GDP per capita and its growth rates. The results of correlation analysis we complement with descriptive analysis of the development in time, which showed in figure 2. The choice of indicators of GDP and government stability explains via successes and failures of transformational reforms in Ukraine. 


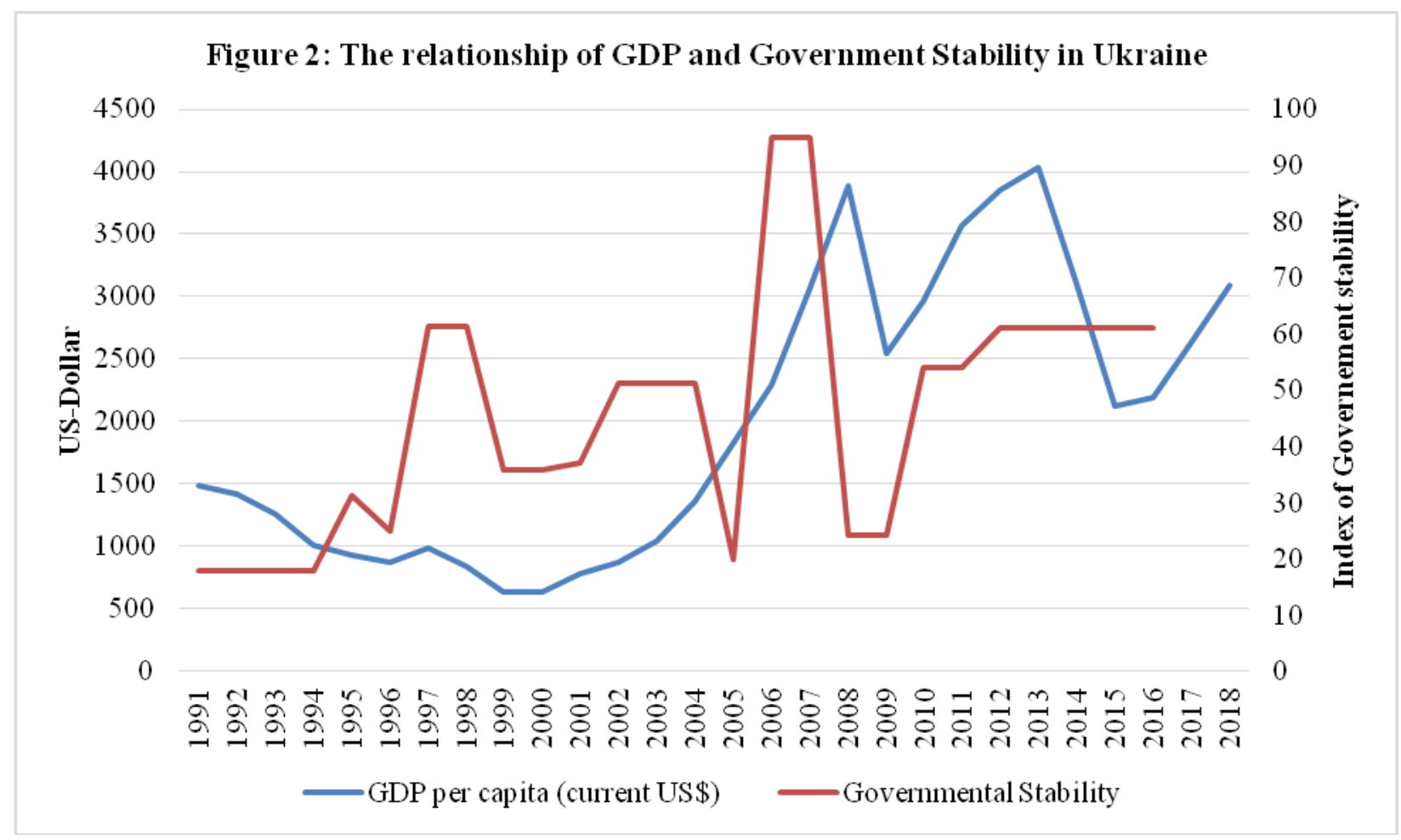

Source: authors' calculations based on Worldbank Database.

The graph shows two downward shifts on government stability curve in 2005 and 2008. The first shift was explained by the government change during period of orange revolution late November 2004 - January 2005. The second move was reflection of the political consequences of the global financial crisis 2008-2009. The significant increase in government stability correlates with the period of democratic reforms in 2005 - 2008. After this period the negative consequences of global financial crisis for Ukrainian economy can be seen at the downturn part of the government stability curve. The political and economic changes lead to the election of the new President, new Verhovna Rada, adoption of new laws, empowerment of workers at local level are shown at the upswing part of the government stability curve. In general, changes in the government stability curve show the economic and political reforms' progress and some deviations and inconsistency from their implementation in some periods.

The graph indicates the hypothesis that Government Stability has a delayed effect on GDP. Interpreting the result demonstrates that GDP changes were reflected on fluctuations of values of government stability given the changes in political situation in the country in the period 1991-2016.

The graph of GDP and political stability illustrates the tendency of decreasing trust to the government explains during the period of Orange revolution in Ukraine. The way for fundamental reforms is opened, but it has narrowed considerably amid political resistance to anticorruption reforms and attacks on civil society and the media. For the first time since the 2014 revolution, Ukraine's Democracy Score declined this year. In other countries, informal leaders operating outside of or on edges of accountable institutions increasingly dominate their undeveloped political systems (Freedom House Report, 2018). The estimation results prove the necessity of widespread reform in formation democratic institutions at the state and local levels. 

in society.

The research is complicated by the lack of sufficient data reflecting the underlying processes

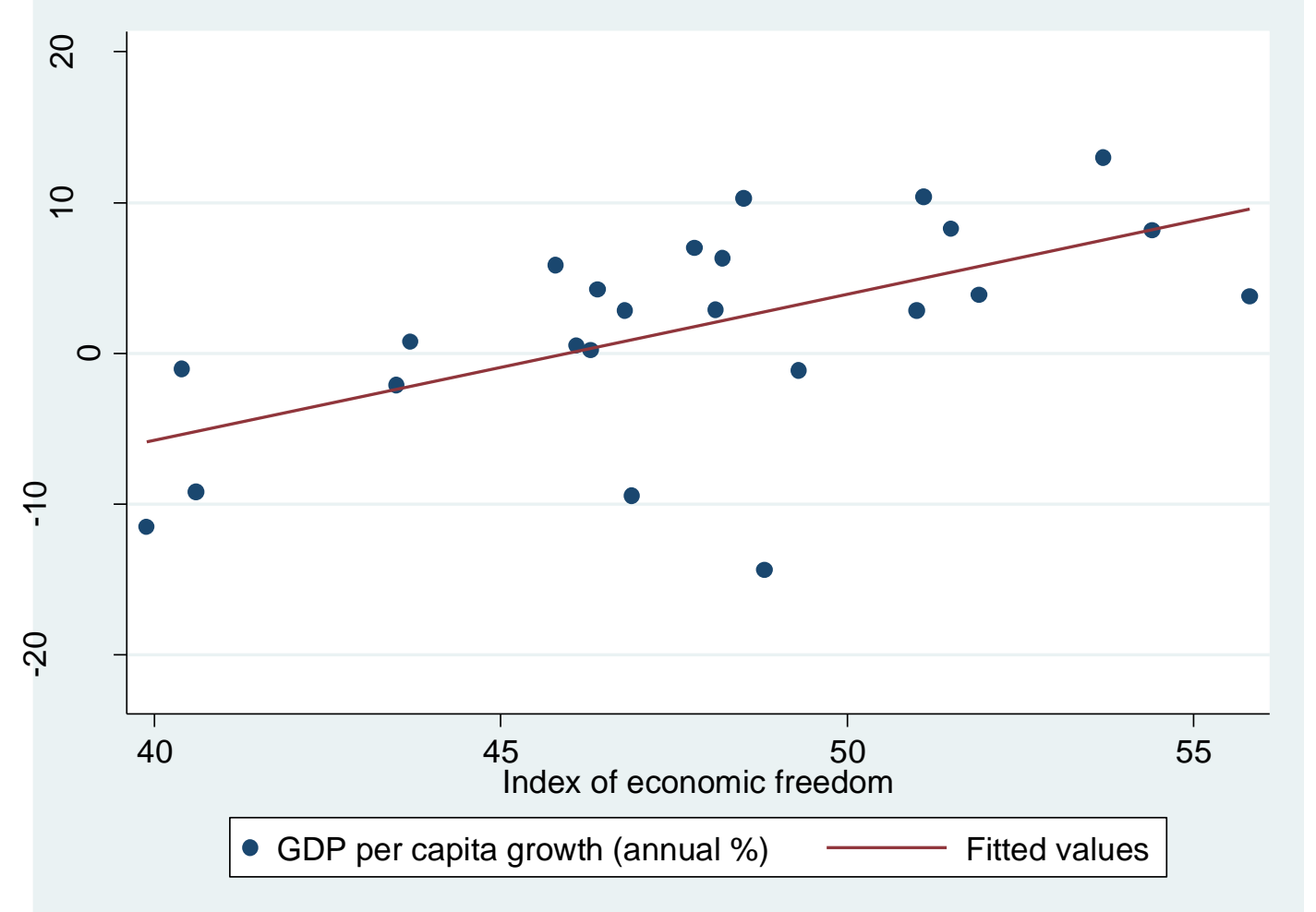

Figure 3: Correlation GDP per capita and Index of Economic Freedom

Source: authors' calculations based on Worldbank Database.

Corruption continues play critical role in decision-making process in Ukraine. The business model of Ukrainian oligarchs based on competitive advantages in the domestic market, and welldeveloped political connections in an environment marked by limited rule law and insecure property rights. Accordingly, oligarch business in Ukraine is not matter of international expansion but instead concerns of the prevention competition in the domestic market and a strong reliance on non-transparent transnational offshore network to conceal ownership and profits (Pleines, 2017, p. 171).

Ukraine scored 56.99 points out of 100 on the 2018 Global Competitiveness Report published by the World Economic Forum, which confirm the low efficiency and labour productivity. Ukraine ranked 71 among 190 economies in the ease of doing business, according to the latest World Bank annual ratings. The rank of Ukraine improved to 71 in 2018 from 76 in 2017. Ease of Doing Business in Ukraine averaged 112.36 from 2008 until 2018, reaching an all-time high of 152 in 2011 and a record low of 71 in 2018 (Ease of Doing Business in Ukraine, 2019).

Rent seeking opportunities arising from arbitrage between the reformed and unreformed sectors of the economy remain the most visible legacy of Ukraine's incomplete economic transition. The arbitrage continues to generate highly concentrated rents to powerful special stakeholders' interest groups, and to undermine the effectiveness and the resilience of Ukraine's economic institutions.

The effective economic order means concurrence of personal and public outcomes of economic activity. The legal guarantees of economic agents provided by the effective operation of an integrated institutional system in the society. The analysis of miscellaneous theories indicates the necessity of the comprehensive research's approach.

The research reflects the complementary tendency for system transformation process in Ukraine. The correlation analysis illustrates degree of relationship between variable, where moderate correlation coefficient is for GDP from government stability, from index of economic freedom, and absence of corruption. 
The estimation results confirm the theory of substantial change of political and social systems (Merkel et al, 2019). The change of the institutional environment and patterns of behavior, of economic agents alter the entire social structure of institutions. Increase in confidence in justice and government stability should result in GDP per capita growth. Government stability reflects continuity and sequencing of political and economic reforms. The continuation research of the forms of interdependence and the ways for stimulating reforms will provide the feedback of research for its practical application.

Conclusions. The paper provides the supporting science needed to develop and execute policies, as well as offering persuasive evidence to policy-makers of the potential national and corporate benefits of these policies. The system transformation is the complex process where mechanical coping and change institutions do not provide quantitative changes, and need development of formal rules and informal institutions and consciousness, including mentality. The theories' systematization aims to turn the research paradigm in the direction of deep understanding process, forms, and mechanisms. The analysis of transformation demonstrates significant differences in the conditions, procedures, and results in transformation process in Ukraine. The estimation results confirm the necessity of widespread political and economic reforms in the direction of democratic state formation. The outcomes of correlation analysis single out factors that creation new institutions and renovation old ones, as well inclusion various groups of population in all regions might lead to a more sustainable strategy of political and social - economic development in Ukraine.

\section{References}

1. Aslund A. (2009). How Ukraine Became a Market Economy and Democracy. Washington D.C. The Peterson Institute for International Economics. 345 p.

2. Baron J., Wilkinson-Ryan T. (2018). Conceptual foundations: a bird's-eye view.) In: Teitelbaum J C., Zeiler K. (ed.), Research Handbook on Behavioral Law and Economics, Edward Elgar Publishing.

3. Beichelt T. (2012). Prinzip "Worst Practice?" Demokratiedefiziente Regimeelemente und die Wechselwirkungen mit der EU-Ebene. No.01. Institut für Transformationsstudien. Viadrina.

4. Bertelsmann Stiftung, BTI 2003, 2006, 2008, 2010, 2012, 2014, 2016, 2018 - Ukraine

Country Report. Gütersloh: Bertelsmann Stiftung, 2003, 2006, 2007, 2010, 2012, 2014, 2016, 2018.

5. Boakye S. (2007). Theory of Social Transformation, Political Transition and Economic Growth 〈http://ssrn.com/abstract $=1076568 \mathrm{pdf}>$

6. Boettke P.J., Leeson P.T., eds. (2015). The Economic Role of the State. Northampton: Edward Elgar Publishing.

7. Carothers T. (2002). The End of the Transition Paradigm. Journal of Democracy. No. 13.

8. Corbo V., Coricelli F., Bossak J. eds. (1991). Reforming Central and Eastern European Economies: Initial Results and Challenges, The World Bank Washington, D.C.

9. Clague C. ed. (1997). Institutions and Economic Development. Growth and Governance in Less Developed and Post-Socialist Countries, The John Hopkins University Press.

10. David P.A. (2010). Path Dependence, its Critics and the Guest for 'Historical Economics. In Garrouste P., Ioannides S. ed., Evolution and Path Dependence in Economic Ideas, Edward Elgar Publishing.

11. Democracy Barometer. 2018. <http://www.democracybarometer.org/dataset_en.html>

12. Drahokoup J. (2009). After Transition: Varieties of Political Economic Development in Eastern Europe and the Former Soviet Union. Comparative European Politics. No 7 (2). June.

13. Ease of Doing Business in Ukraine, 2019. Ease of Doing Business in Ukraine (2019). < https://tradingeconomics.com>Ukraine>

14. Fadda, S. (1992). Underdevelopment in Southern Italy: Macroeconomic Relations and Microeconomic Bases. Regional Policy. Vol. 12. 
15. Gigante A.A. (2016). Reviewing Path Dependence Theory in Economics: MicroFoundations of Endogenous Change Processes. MPRA Paper. <https://mpra.ub.unimuenchen.de/75310/>

16. Glinkina S., Kulikoa N. (2015). Market Borrowing Institutes of Developed Countries: Experience of Central-Eastern Europe. (in Russian) DOI: http://dx.doi.org/10.15211/soveurope42015105117

17. Guiso L., Sapienza P., and Zingales L. (2006). Does Culture Affect Economic Outcomes? Journal of Economic Perspectives, Volume 20, Number 2, Spring: 23-48.

18. Gurenkova O.V. (2016). Features of the Process of Transformation of Society in Modern Russia. Scientific and Methodological Electronic Journal "Concept", № S5. <http://ekoncept.ru/2016/76061.htm>

19. Gomulka S. (1994). Lessons from Economic Transformation and the Road Forward. CASE Network Studies and Analyses. No. 17. March.: https://ssrn.com/abstract=1476813

20. Goorha P. (2017). Modernization Theory. Oxford Research Encyclopedia of International Studies. March. https://www.researchgate.net/publication/301731821

21. Kaldaru H. \& Parts E. (2008). Social and institutional factors of economic development: evidence from Europe, Baltic Journal of Economics,8:1:,29-51, DOI:10.1080/1406099X.2008.10840444

22. Henderson J. (2019). On Appropriate Models for Transformation in Eastern Europe. In Henderson J. (ed.), Industrial Transformation in Eastern Europe in the light of the East Asian Experience, Springer.

23. Herrendorf B., Rogerson R., Valentinyi A. (2013). Growth and Structural Transformation NBER Working Paper Series. Working Paper 18996. April. <http://www.nber.org/papers/w 18996 > 24. Hodgson G.M. (2006). Institutions, Recessions and Recovery in Transitional Economies. Revista de Economia Institucional. December. <htpps://www.researchgate.net/publication/228289774 >

25. Hölscher K., Wittmayer J.M., Loorbach D. 2018. Transition versus transformation: What's the difference? Environmental Innovation and Societal Transitions 27: 1-3. <http:// www.elsevier.com/locate/eist>

26. Ioannides, S. (2008). The Problem of Knowledge in Economics: Prices, Contracts and the Organizations. In Hannapi H., Elsner W. (ed.), Advances in Evolutionary Institutional Economics. Evolutionary Mechanisms, Non-Knowledge and Strategy, Edward Elgar Publishing Limited.

27. Kahler M. (1988). Organization and Cooperation: International Institutions and Policy Coordination. Journal of Public Policy. Vol. 8, No. 3/4, International Monetary Cooperation, Domestic Politics, and Policy Ideas (Jul. - Dec., 1988), pp. 375-401. Published by: Cambridge University Press.: <https://www.jstor.org/stable/4007190 >

28. Knight J. (1992). Institutions and Social Conflicts. Cambridge.

29. Lane D. (2016). Divergent Social and Economic Consequences of Transformation in Postcommunist States. Mir Rossii, vol. 25, no 4, pp. 7-29 (in Russian).

30. Merkel W., Kollmorgen R., Wagener H-J. (eds) (2019), The Handbook of Political, Social, and Economic Transformation, Oxford University Press.

31. Miller T., Kim A.B., Roberts J.M. 2019. Index of Economic Freedom. 25 Anniversary Edition. Heritage Foundation. Washington D.C.

32. Nosova O.V. (2017). The Impact of Globalization on Financial Institutions' Development. Europa Regionum. Tom XXX. Household Finance, Uniwersytet Szczecinski, № 1: 99 -119.

33. Pezoldt K., Koval A.G. (2018). Challenges of the Theory of System Transformation in Economics. Questions of Economic Theory. Macroeconomics. No.4. (in Russian).

34. Pleines H., (2017). The International Links of Ukrainian Oligarchs. Business Expansion and Transnational Offshore Networks. Beichelt T., Worschech S. (ed.), Transnational Ukraine? Networks and Ties that Influence(d) Contemporary Ukraine, Stuttgart: 161-179.

35. Polanyi K. (2001). The Great Transformation: The Political and Economic Origins of our Time. Boston, MA: Beacon Press. 
36. Rabie M. (2013). Global Economic and Cultural Transformation. The Making of History. Palgrave Macmillan. 219 p.

37. Thomas H., Hendrick-Wong Y. (2019). Inclusive Growth. The Global Challenges of Social Inequality and Financial Inclusion. Emerald Publishing.

38. Tridico P. (2014). Institutional Change and Economic Performance in Transition Economics: The case of Poland. University Sussex European Institute Working Paper. No 74.

39. Wallace C., Haerpfer C. (1998). Three Paths of Transformation in Post-Communist Central Europe. Reihe Soziologie / Sociological Series. Institute for Advanced Studies, Vienna. No.28, May.

40. Swift R. (2014) Alternatives to Capitalism. New Internationalist Publications Ltd.

41. Ukraine Competitiveness Rank. (2019). < https://tradingeconomics. com>ukraine>competitivess-rank>

42. 2019 Index of Economic Freedom. (2019). World Heritage Foundation. https://www.heritage.org/index/about >

43. Ukraine Growth Study Document. Faster, Lasting and Kinder. (2018). The Institute for Economic Research and Policy Consulting.

44. Zaslavskay T.I. (2010). Societal Transformation of Russian Society: Activity-Structural Concept.- Moscow.

45. Satuniene Z. (2010). Permanent Instability of Ukraine's Political Regime. Foreign Policy Research Center.

46. Worldwide

Governance

Indicators.

Worldbank

Database. https://info.worldbank.org/governance/wgi/Home/Documents\#wgiOverTime>

47. Zweynert, J., \& Goldschmidt, N. 2006. The Two Transitions in Central and Eastern Europe as Processes of Institutional Transplantation. Journal of Economic Issues,40 (4), 895-918. https://www.jstor.org/stable/4228315> 